\title{
Age of the Vindhyan Supergroup: A review of recent findings
}

\author{
JYOTIRANJAN S RAY \\ Physical Research Laboratory, Navrangpura, Ahmedabad 380 009, India. \\ e-mail: jsray@prl.res.in
}

The Vindhyan Supergroup of India is one of the largest and thickest sedimentary successions of the world. Deposited in an intra-cratonic basin, it is composed mostly of shallow marine deposits. It is believed to have recorded a substantial portion of Proterozoic time and therefore, likely to contain valuable information on the evolution of the atmosphere, climate, and life on our planet. It also contains some of the most disputed fossils of earliest animal life. Despite their importance, the absolute age of these rocks had remained unknown until recently. In this work I evaluate all the recent chronological information and discuss their implications. From the present findings it appears that the issues surrounding the age of the Lower Vindhyans in the Son valley are now resolved, whereas problems with the age of the Upper Vindhyans and that with the stratigraphic correlations remain to be answered.

\section{Introduction}

The Vindhyan Supergroup is the thickest Precambrian sedimentary succession of India and the duration of its deposition is one of the longest in the world. Since the earliest descriptions by Oldham (1856), Mallet (1869) and Auden (1933) the Supergroup has received a great deal of attention, and volumes of geological and geophysical data have been gathered. Many of these data have been reviewed at various times during the last 150 years (e.g., Valdiya et al 1982; Sastry and Moitra 1984; Bhattacharya 1996; Bose et al 2001). The importance of the Vindhyan sequences lies in the notion that because of its vastness in time and space they contain important information on the evolution of the Earth's atmosphere, climate, sedimentary cover and life. However, even after decades of scrutiny we have not fully understood all the records that were uncovered from these rocks. The biggest challenge has been the difficulty in establishing links between the records found with global phenomena, because we have not yet determined with certainty the timings of the local events.
Although the Vindhyans have been the focus of numerous interesting fossil discoveries for decades, the recent discoveries of non-Ediacaran trace fossils (Seilacher et al 1998) and animal body fossils (Azmi 1998) in the lower part of the Supergroup have generated renewed interest in these rocks. These discoveries, although their authenticity did not last the test of time, have re-established the belief that these sequences possess important information on the evolution of life on our planet. Geochemical and isotopic investigations on the Vindhyan rocks (e.g., Kumar et al 2002; Ray et al 2003) have also shown that there exists a host of valuable information of global importance that could change our views on the Proterozoic environment. However, any meaningful scientific investigation in the Vindhyans must be based on reliable geochronological information, most of which is usually obtained from radioisotope dating. For a very long time such data were limited in number and many were contentious because of the limitations of the methods or the use of unsuitable samples. Another stumbling block in Vindhyan Geology has been the lack of good stratigraphic

Keywords. Vindhyan Supergroup; geochronology; U-Pb zircon dating; isotope stratigraphy. 
correlations between various parts of the basin. In the absence of good biostratigraphic markers the correlations would have to depend on geochronology and chemostratigraphy. In this contribution I compile recent geochronological information, test its reliability, and discuss its implications. Only those data that are published in peer-reviewed journals have been considered here; none of the preliminary results reported in conferences find a place in this review. An attempt has also been made to bring to light the gaps in our knowledge and propose a meaningful future course of action.

\section{Geology and correlations}

The Vindhyan basin is bounded to the west by the Aravalli Mountains along the Great Boundary Fault but is believed to continue uninterrupted beneath the Gangetic alluvial plain beyond the present northern outcrop limit (e.g., Verma 1991), and below the Deccan Traps in the southwest. The Bijawar Group borders the southeast margin of the basin. Figure 1 gives a geological map and a simple lithological framework of the Vindhyan Supergroup. The rocks of the Supergroup are exposed in two sectors: Rajasthan in the west and Son valley in the east. However, in this paper I treat the Vindhyans of Chitrakut-Majhgawan sector in the north (figure 1) separately because of their distinct lithological properties (e.g., Singh and Kumar 1978).

The general belief that many of the Vindhyan formations of Rajasthan are laterally correlatable with those in the Son valley is difficult to establish in the absence of physical continuity. Biostratigraphic correlation in the Vindhyans, like the Proterozoic sequences elsewhere in the world, is not robust. Existing data from carbon and strontium isotope stratigraphy in carbonate formations do not support this hypothesis (Ray et al 2003). A similar correlation problem exists between the Vindhyans of Chitrakut-Majhgawan sector and that of the Son valley (e.g., Ray et al 2003).

The Vindhyan strata are unmetamorphosed and mostly undeformed. However, there exist largescale folds in the Son valley and several post depositional faults in Rajasthan (e.g., Verma 1996; Srivastava and Sahay 2003; Chakraborty, this issue). The Upper Vindhyans in the BundiSapotra-Karauli sector in Rajasthan are significantly affected by reactivations of the Great Boundary Fault (e.g., Verma 1996) and hence stratigraphic correlation is tricky. Evidence for any global or local event found in these formations must therefore be linked carefully with those reported elsewhere in the basin.
The Vindhyan Supergroup is composed mostly of low dipping formations of sandstone, shale and carbonate, with a few conglomerate and volcaniclastic beds, separated by a major regional and several local unconformities (e.g., Bhattacharyya 1996). The regional unconformity occurs at the base of the Kaimur Group (figure 1) and divides the sequence into two units: the Lower Vindhyans (Semri Group) and the Upper Vindhyans (Kaimur, Rewa and Bhander Groups). The outcrop pattern of the Supergroup resembles a simple saucershaped syncline (figure 1). It is generally believed that the Vindhyan basin was a vast intra-cratonic basin formed in response to intraplate stresses (e.g., Bose et al 2001). Detailed stratigraphy of the Supergroup has been discussed in numerous contributions (see reviews in Bhattacharyya 1996).

\section{Geochronology prior to 1998}

\subsection{Radioisotope age data}

Venkatachala et al (1996) published a comprehensive review of geochronological information on the Vindhyans. In spite of minor inconsistencies the available data supported the conventional belief that the Vindhyan strata were deposited between the earliest Mesoproterozoic and latest Neoproterozoic (1400-600 Ma). Barring some indirect information from carbonaceous mega fossils and stromatolites (e.g., Kumar and Srivastava 1997; Rai et al 1997, table 1), most of the pre 1998 chronological information came from a large number of $\mathrm{K}$-Ar ages, mostly from the work of Vinogradov et al (1964). However, the $\mathrm{K}-\mathrm{Ar}$ dating method is known to be notoriously unreliable for sedimentary rocks that have undergone deep burial diagenesis (e.g., Faure 1986). In addition, the method has its own limitations owing to high mobility or loss of $\mathrm{K}$ and $\mathrm{Ar}$ in open sedimentary systems. There have been reports of numerous Fission-Track $(\mathrm{F}-\mathrm{T})$ ages as well, for authigenic glauconites (e.g., Srivastava and Rajagopalan 1986, 1988, 1990; Srivastava et al 1985). The most common problem with this method is the fading of tracks due to thermal annealing, which introduces large errors in the estimated dates (Faure 1986). Therefore, the $\mathrm{F}-\mathrm{T}$ dates should be considered only as minimum ages. In addition, both the $\mathrm{K}-\mathrm{Ar}$ and $\mathrm{F}-\mathrm{T}$ ages of the Vindhyan formations have unacceptably large errors $(>15 \%)$. The only reliable pre-1998 age information comes from comparable $\mathrm{Rb}-\mathrm{Sr}$ isochron dates reported by Crawford and Compston in $1970(1140 \pm 24 \mathrm{Ma})$ and later by Kumar et al in 1993 (1067 $\pm 31 \mathrm{Ma})$ of a lamproite 


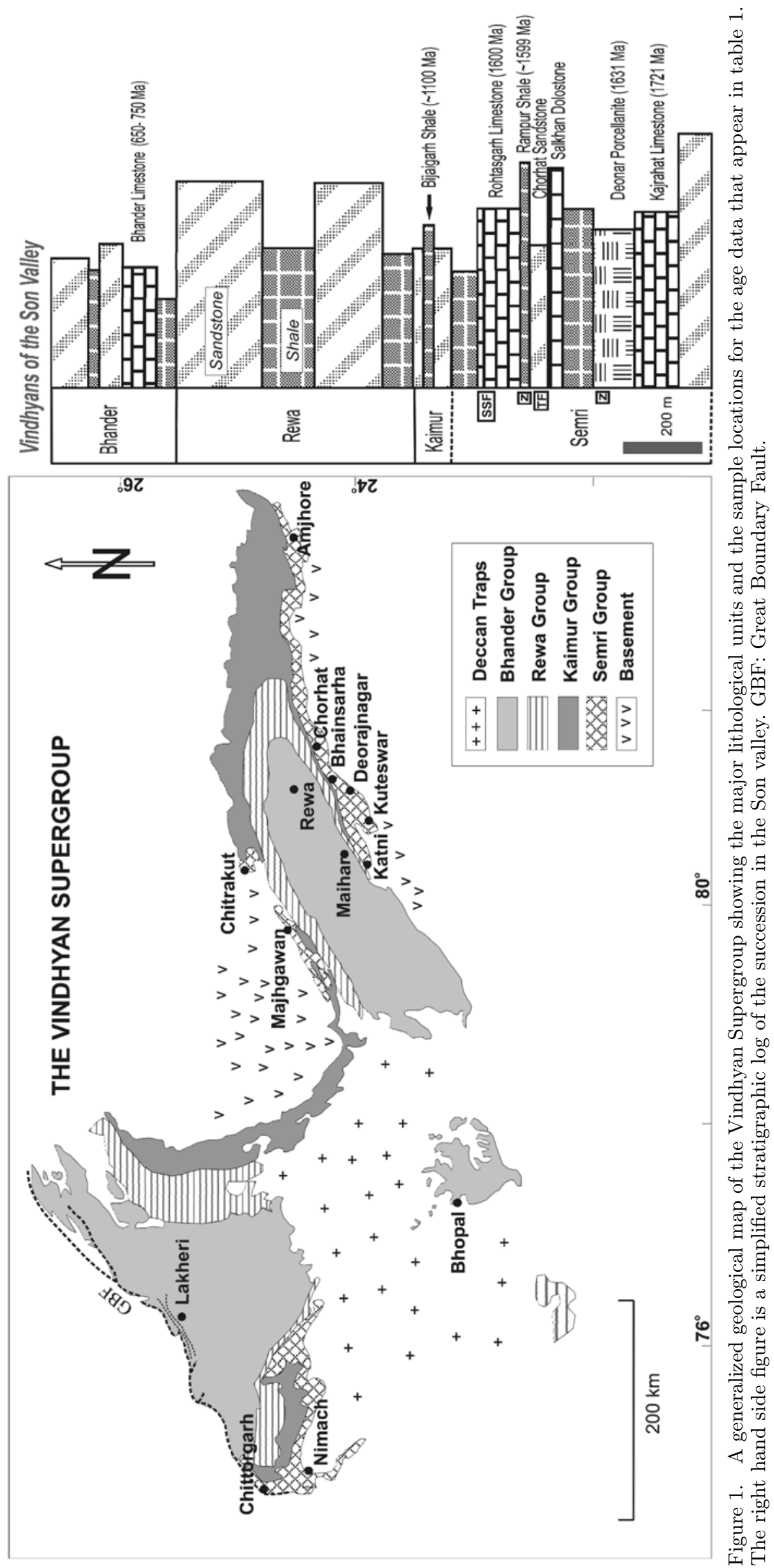




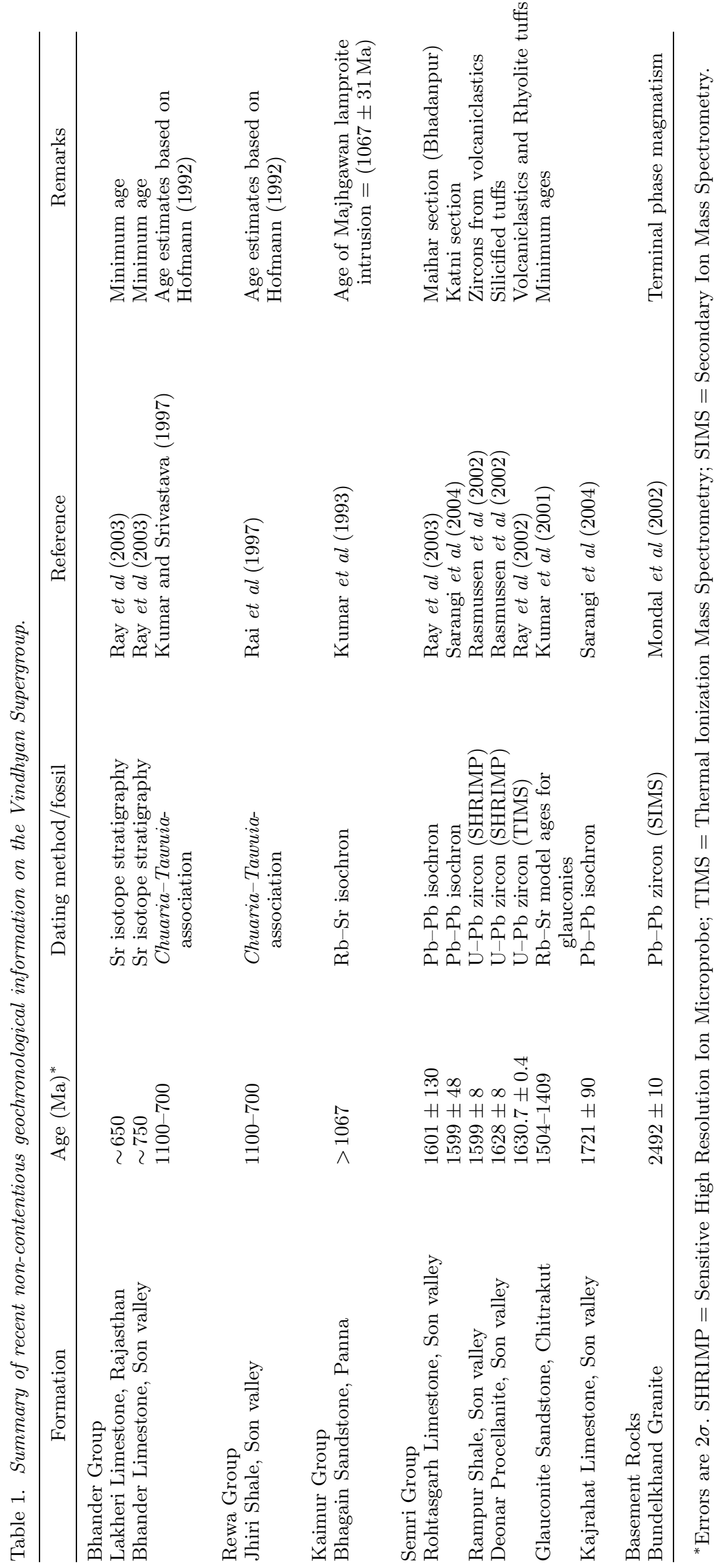


pipe that intrudes the lower part of the Kaimur Group at Majhgawan (figure 1). These age data unambiguously make the Semri Group older than 1100 Ma.

\subsection{Vindhyan fossil controversy}

In 1998, a paper in Science (Seilacher et al 1998) reported discovery of the oldest known trace fossils of multicellular animals (non-Ediacaran) in Chorhat Sandstone (Semri Group), which was believed to be $\sim 1100 \mathrm{Ma}$ old based on $\mathrm{K}-\mathrm{Ar}$ and $\mathrm{F}-\mathrm{T}$ ages. This discovery suggested that the timing of the emergence of advanced life forms is nearly twice as old as the nearest well-dated multicellular organisms (565 Ma old Ediacara, Narbonne and Gehling 2003). At the time when the accuracy of these findings were being assessed an even more remarkable discovery of animal body fossils [Small Shelly Fossils (SSF)], usually found in much younger rocks ( $<550 \mathrm{Ma})$, was reported from the overlying Rohtasgarh Limestone by Azmi (1998). While Seilacher et al (1998) relied on existing age data, Azmi's (1998) claims certainly made the Vindhyans much younger $(600-530 \mathrm{Ma})$. In yet another controversial finding Kathal et al (2000) reported an Ediacaran fossil, Spriggina floundersi, from the Semri Group of Chitrakut-Majhgawan sector. But the authors themselves had doubts about the authenticity of the fossil. Even though none of these findings were approved by the scientific community at large (e.g., Morris et al 1998; Brasier 1999; Rai and Gautam 1999; Kumar 2001), the need for robust age data became imperative.

\section{Post 1998 geochronology}

Prior to the age controversy generated by the fossil discoveries, it was generally understood that the Vindhyan Supergroup being stratigraphically confined between the Bijawar Group/Bundelkhand Granites/Aravalli Supergroup and the Gondwana Supergroup was Proterozoic in age. However, owing to the lack of reliable biostratigraphic information and the inferior quality of available radioisotope age data, ages of individual formations or groups were poorly understood. Thus although the age of Majhgawan lamproite put a lower limit of $1100 \mathrm{Ma}$ for the Lower Vindhyans in the northern sector, the validity of this scenario in the entire basin was uncertain (Mitra 1996). These difficulties have led to a renewed research interest in the Vindhyans. New age data appeared using both absolute and relative dating methods. Attempts were also made to correlate various sectors using isotope stratigraphic principles. In the following discussion I shall present a review of all these studies (table 1), and make an effort to discuss the advantages and limitations of the methods as well. The errors on all the dates compiled in this paper are $2 \sigma$.

The determination of absolute depositional ages of clastic sedimentary formations is exceptionally difficult, and unequivocal age estimates cannot usually be obtained using the common long-lived isotope systems such as $\mathrm{U}-\mathrm{Pb}, \mathrm{Sm}-\mathrm{Nd}$, and $\mathrm{Rb}-$ $\mathrm{Sr}$, because minerals in these rocks inherit their provenance isotopic characteristics and are variably affected by diagenetic overprints. However, the Re-Os systematics in organic rich black shales, that often behave as closed system, can be used to date clastic sedimentary sequences (Ravizza and Turekian 1989). In addition, dating of volcaniclastic rocks has been a very successful method in sedimentary sequences as these rocks contain primary zircons that can be dated by the U-Pb method (Bowring and Schmitz 2003). Sometimes carbonates can also be dated by $\mathrm{Pb}-\mathrm{Pb}$ method if proper sampling of least altered components, which might have remained effectively as closed systems, can be done (e.g., Moorbath et al 1987; Jahn et al 1990).

\subsection{Rb-Sr dating of diagenetic glauconites}

In spite of the known complexities, Kumar et al (2001) dated sedimentary glauconites from sandstone formations of the Semri Group near Chitrakut by the Rb-Sr method. Because of their careful experimentation they could determine good model ages for these formations. Based on these ages (1531-1409 Ma) they suggested that the onset of the earliest Vindhyan sedimentation could not have been later than 1600 Ma. However, the uncertainty in the correlation of these formations with the Semri Group strata in the Son valley restricts a basin-wide generalization.

\section{$4.2 \mathrm{U}-\mathrm{Pb}$ zircon dating}

Subsequent to Kumar et al's (2001) work two independent groups reported U-Pb zircon ages for the Deonar Porcellanite Formation and Rampur Shale of the Semri Group in the Son valley (figure 1) in the same issue of the journal Geology (Ray et al 2002; Rasmussen et al 2002). Deonar Formation is composed of silicified volcanic rocks (rhyolites) and very fine-grained volcaniclastic sediments in which the occurrence of primary volcanic zircons was noticed. Ray et al (2002) dated zircons from two samples from this formation collected at two different localities in the Son valley (figure 1): Bhainsarha $\left(24^{\circ} 16.37^{\prime} \mathrm{N}, 81^{\circ} 21.10^{\prime} \mathrm{E}\right.$; figure $\left.2 \mathrm{~A}\right)$ and Deorajnagar $\left(24^{\circ} 08.23^{\prime} \mathrm{N}, 81^{\circ} 12.50^{\prime} \mathrm{E}\right)$. The zircon samples, analysed using a Thermal Ionization Mass-spectrometer (TIMS), yielded identical 

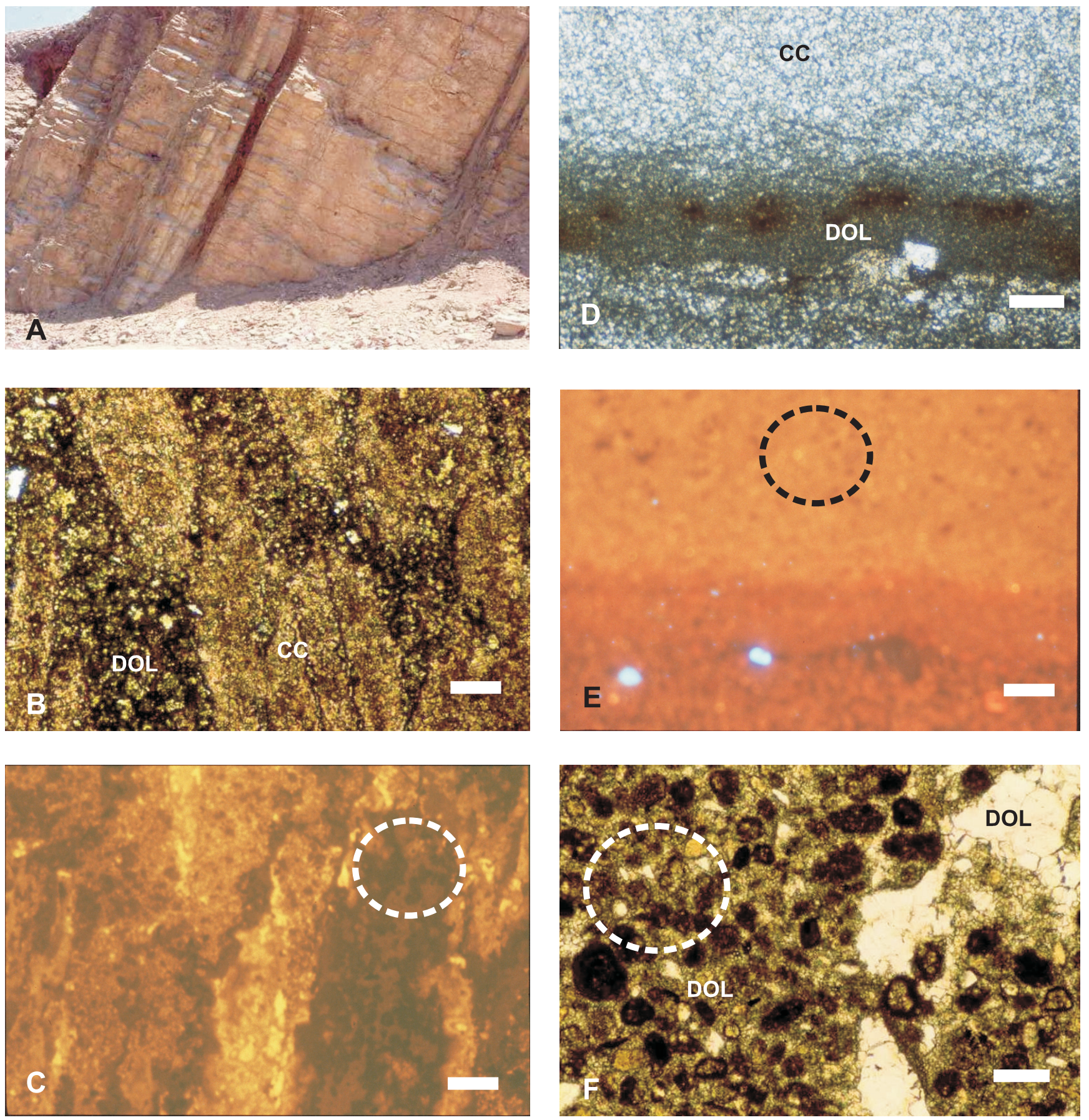

Figure 2. (A): Field photograph of Porcellanite Formation at Bhainsarha, Son valley. (B)-(F): Photomicrographs of carbonate thin sections. (B): A stained section of the Kajrahat Limestone from Kuteswar under plane polarized light showing replacement structures. (C): A CL image of the B showing bright red and dull luminescence for replacement minerals and some non-luminescent calcites. (D): Rohtasgarh Limestone (not stained) under plane polarized light showing a microbialite band and microspar matrix. (E): A CL image of D showing brick red luminescence for dolomites and medium red luminescence for the calcite matrix. (F): The Salkhan Dolostone in plane polarized light showing ooids in microspar matrix and coarse dolospar cements. Length of scale is $200 \mu \mathrm{m}$. The dashed circles show sites of samples taken for isotope studies. cc: calcite and dol: dolomite.

concordant ages of $1631.2 \pm 5.4 \mathrm{Ma}$ and $1630.7 \pm$ $0.8 \mathrm{Ma}$. Rasmussen et al (2002) analysed zircons from the same formation exposed near Chorhat using a Sensitive High Resolution Ion Microprobe (SHRIMP). Remarkably the age reported by them,
$1628 \pm 8 \mathrm{Ma}$, is indistinguishable from the ages reported by Ray et al (2002). Such observations clearly brought out the strength of radioisotope dating. The age of the Deonar Formation that occurs below the controversial fossil discoveries 
can now be set unequivocally at $1630.7 \pm 0.8 \mathrm{Ma}$, the weighted mean of all three ages.

Rasmussen et al (2002) also reported two U-Pb ages for zircons from a rhyolitic tuff layer present within the Rampur Shale (figure 1). These indistinguishable ages of $1602 \pm 10 \mathrm{Ma}$ and $1593 \pm 12 \mathrm{Ma}$ $($ Mean $=1599 \pm 8 \mathrm{Ma})$ clearly indicate that the trace fossils found by Seilacher et al (1998) are Paleoproterozoic in age, thus making them the oldest known trace fossils in the world.

Zircon is an incredible mineral as it survives weathering and metamorphism. Zircons found in a given sedimentary formation can come from a variety of sources. U-Pb dates on such zircons indicate the age of formation of its original source. However, such incorporated zircons are likely to show effects of transportation. These abraded zircons can easily be differentiated from primary euhedral magmatic zircons. The zircons dated by Ray et al (2002) and Rasmussen et al (2002) are primary igneous zircons because they are

- from volcanic tuff layers,

- clear and euhedral crystals, and

- display fine oscillatory growth zoning.

Therefore, the possibility that they represent zircons from older formations is simply ruled out. In addition, there is no evidence found up till now for a $\sim 1631$ Ma old magmatic event below the Porcellanite Formation in the Vindhyan Supergroup or in its provenance.

\section{$4.3{ }^{206} \mathrm{~Pb}-{ }^{207} \mathrm{~Pb}$ dating of carbonates}

Determination of depositional age for sedimentary sequence can also be achieved by direct dating of sedimentary carbonates using the whole-rock $\mathrm{Pb}-$ $\mathrm{Pb}$ method (Moorbath et al 1987). The principles of this method are based on chemical fractionation of $\mathrm{U}$ from $\mathrm{Pb}$ and consequent variation in ${ }^{206} \mathrm{~Pb} /{ }^{204} \mathrm{~Pb}$ and ${ }^{207} \mathrm{~Pb} /{ }^{204} \mathrm{~Pb}$ ratios (Jahn 1988). Sedimentary carbonates are known to possess high and variable $\mathrm{U} / \mathrm{Pb}$ ratios, and are therefore suitable candidates for whole-rock $\mathrm{Pb}-\mathrm{Pb}$ dating. The Vindhyan Supergroup contains four carbonate formations, three in the lower Vindhyans and one in the upper Vindhyans (figure 1). Once sampled, it was a matter of time before $\mathrm{Pb}-\mathrm{Pb}$ isochron dates became available.

In the first such attempt, Ray et al (2003) successfully dated the Rohtasgarh Limestone from Son valley and reported an age of $1601 \pm 130 \mathrm{Ma}$. Samples for this work came from a quarry at Bhadanpur $\left(24^{\circ} 10.4^{\prime} \mathrm{N} \quad 80^{\circ} 50.8^{\prime} \mathrm{E}\right)$ near Maihar (figure 1). Five unaltered, dolomite free carbonate components were hand picked from three whole-rock samples for this work after careful petrographic documentation to avoid late diagenetic products (Ray et al 2003). In spite of all the precautions the error on the age was high because some physically inseparable dolomites, having lower U contents, inadvertently got incorporated in the final aliquot.

About a year later, Sarangi et al (2004) published high quality $\mathrm{Pb}-\mathrm{Pb}$ age data using a large number of sub-samples (components) for the Rohtasgarh Limestone. They reported an age of $1599 \pm 48 \mathrm{Ma}$, which is indistinguishable from the age reported by Ray et al (2003). Their samples came from a section near Katni (figure 1), $550 \mathrm{~km}$ southwest of Ray et al's sampling site. Once again two independent studies have reported identical ages for a single formation at two different localities. Unambiguously, the age of deposition of the Rohatsgarh Limestone is $1600 \pm 44 \mathrm{Ma}$. This is clearly in conflict with the claim made by Azmi (1998) that the formation contains SSF of Cambrian age.

In the same contribution Sarangi et al (2004) also reported a couple of $\mathrm{Pb}-\mathrm{Pb}$ isochron ages for the Kajrahat Limestone, the lowermost carbonate formation in the Vindhyans of the Son valley. Because of the high associated errors (1729 \pm $110 \mathrm{Ma}$ and $1707 \pm 190 \mathrm{Ma}$ ) they did not give much importance to these numbers. However, considering that these are the only reliable numbers available from the bottom of the sequence they should be used for any stratigraphic interpretations. The weighted mean of these ages, $1721 \pm 90 \mathrm{Ma}$, should be taken as the age of deposition of the Kajrahat Limestone. Also the lowest measured ${ }^{87} \mathrm{Sr} /{ }^{86} \mathrm{Sr}$ in these carbonates (0.70460; Ray et al 2003), which likely reflect the composition of the contemporary seawater, is not in conflict with this age. This age suggests that the initiation of deposition in the Vindhyan basin took place before $1721 \mathrm{Ma}$.

\subsection{Sr-isotope stratigraphy}

As has been discussed earlier, determination of the absolute ages of deposition of sedimentary sequences is challenging. It has been realized that this problem can be overcome with the help of Sr isotope stratigraphy (e.g., McArthur 1994; Veizer et al 1999). ${ }^{87} \mathrm{Sr} /{ }^{86} \mathrm{Sr}$ in unaltered marine carbonates has been established as an effective relative dating tool (e.g., Burke et al 1982). This is possible because ${ }^{87} \mathrm{Sr} /{ }^{86} \mathrm{Sr}$ in the ocean is homogeneous due to the fact that the residence time of $\mathrm{Sr}$ ( 4.0 Ma; Broecker and Peng 1982) is much longer than the mixing times of the oceans $(\sim 1 \mathrm{ka})$. By tying ${ }^{87} \mathrm{Sr} /{ }^{86} \mathrm{Sr}$ of discrete stratigraphic levels to the global seawater evolution curve tied to the geomagnetic polarity time scale or to absolute ages, approximate time gaps and relative depositional 
ages can be estimated. The ${ }^{87} \mathrm{Sr} /{ }^{86} \mathrm{Sr}$ evolution of past seawater as recorded in marine carbonates has already been in use as a successful geochronological tool for the marine carbonates of the Phanerozoic. For the Precambrian, such application is hindered by incomplete ${ }^{87} \mathrm{Sr} /{ }^{86} \mathrm{Sr}$ databases and their inadequate temporal resolution. Nevertheless, the first order secular variation of ${ }^{87} \mathrm{Sr} /{ }^{86} \mathrm{Sr}$ during the Precambrian can be utilized as a geochronological tool to assign minimum ages, which means that the formations could be older than the ages determined. The best available ${ }^{87} \mathrm{Sr} /{ }^{86} \mathrm{Sr}$ seawater curve for such work is the one by Shields and Veizer (2002).

The success of Sr isotope stratigraphy depends on one's ability to extract the pristine marine ${ }^{87} \mathrm{Sr} /{ }^{86} \mathrm{Sr}$, which often happens to be the lowest ratio, from a rock that has undergone diagenesis and alteration. This is usually difficult to achieve using whole-rock samples. Therefore, one must identify and sample components from a whole-rock that has the highest potential for yielding primary marine values. A series of petrographic and geochemical tests have been proposed to this effect (e.g., Frank et al 1997; Veizer et al 1999). These include visual identification of the least altered carbonate components by petrographic techniques, such as thin section Cathodoluminescence (CL), staining, X-ray Diffractometry (XRD) and Scanning Electron Microscopy (SEM). The chosen components are then sampled by micro-drilling and analysed for carbon and oxygen isotopic compositions and for concentrations of major/trace elements to further evaluate their pristine nature. The original powders of the best-preserved (or least altered) components should then be analysed for $\mathrm{Sr}$ isotopes ratios. To give an idea about the benefits of carrying out component specific analysis, I have included below a brief discussion based on the results of Ray et al (2003).

Unlike their Phanerozoic counterparts, the Precambrian carbonates do not contain skeletal components but contain simpler non-skeletal allochems (e.g., intraclasts, peleoids). Orthochemical components (carbonate mud and sparry cement) form the major portion of these rocks. Identification of various components for chemical analyses is therefore based chiefly on the nature and extent of diagenetic alteration. Samples are selected from components that

- have pure calcite mineralogy,

- show low degree recrystallization (e.g., micrites and microspars),

- neither show very bright (Mn rich - due to meteoric diagenesis) nor very dull luminescence (Fe rich - due to deep burial diagenesis),

- possess very low $\mathrm{Mn} / \mathrm{Sr}$ ratio, and
- have unaltered/mildly altered $\delta^{18} \mathrm{O}$ compositions.

Carbonate components that satisfy all or most of the above criteria are likely to yield the most pristine marine ${ }^{87} \mathrm{Sr} /{ }^{86} \mathrm{Sr}$. Ray et al (2003) selected the least altered samples from various carbonate formations of the Vindhyans and determined their ${ }^{87} \mathrm{Sr} /{ }^{86} \mathrm{Sr}$.

The lowest ${ }^{87} \mathrm{Sr} /{ }^{86} \mathrm{Sr}$ determined by Ray et al (2003) in Kajrahat Limestone in the Son valley (0.70460) comes from early marine calcite cements (figure 2B). These cements appear to have replaced preexisting gypsums. Calcites are fine grained, and show medium red luminescence (figure 2C). They possess higher $\delta^{18} \mathrm{O}$ value $(-10 \pm 1 \%$ ) compared to other components. Their $\mathrm{Mn} / \mathrm{Sr}$ content is the lowest, which indicates that they were formed in a marine environment. Therefore, the value of 0.70460 can be considered primary and assigned to the seawater from which these rocks precipitated. This ratio has been deemed to be the lowest ratio observed anywhere for $\sim 1700$ Ma old seawater and is clearly much lower (0.7061) than that determined by Kumar et al (2002) from the same formation.

Microspar calcite matrix components that show medium red luminescence (figure 2D, 2E) and have the highest $\mathrm{Sr} / \mathrm{Ca}$ and lowest $\mathrm{Mn} / \mathrm{Sr}$ yield the lowest ${ }^{87} \mathrm{Sr} /{ }^{86} \mathrm{Sr}(0.70479)$ for the Rohtasgarh Limestone in the Son valley (Ray et al 2003). This ratio is in complete agreement with the seawater value at $\sim 1600 \mathrm{Ma}$ (Ray et al 2003), whereas the value determined by Kumar et al (2002) by the whole rock method (0.7052) suggests a depositional age younger than $1000 \mathrm{Ma}$. In fact, these least altered matrix components have been successfully dated by the $\mathrm{Pb}-\mathrm{Pb}$ method (Ray et al 2003). Sr isotope stratigraphy of Salkhan/Kheinjua Formation failed as the sampled horizons were found to be dolostones (figure 2F). Even the component specific analyses yielded radiogenic ratios (>0.71; Ray et al 2003) indicative of heavy alteration during diagenesis. The same was observed in Bhagwanpura and Nimbehera Limestone formations as well (Ray et al 2003).

The lowest ${ }^{87} \mathrm{Sr} /{ }^{86} \mathrm{Sr}$ ratios in the Bhander Limestone of the Son valley (0.70599 and 0.70605) came from mud crack fillings (figure 3A) and microspar matrices (figure 3B, 3C, 3D) of samples collected from two different localities (Bankhuian and Ramnoi, respectively; Ray et al 2003). All of these components are fine-grained calcites devoid of any dolomite. Their non-luminescent CL (figure 3D), low $\mathrm{Mn} / \mathrm{Sr}(<1)$, and unaltered $\delta^{18} \mathrm{O}$ values attest to their primary nature. Therefore, these ${ }^{87} \mathrm{Sr} /{ }^{86} \mathrm{Sr}$ ratios can be considered to reflect that of the coeval seawater. Comparison of these values with the 

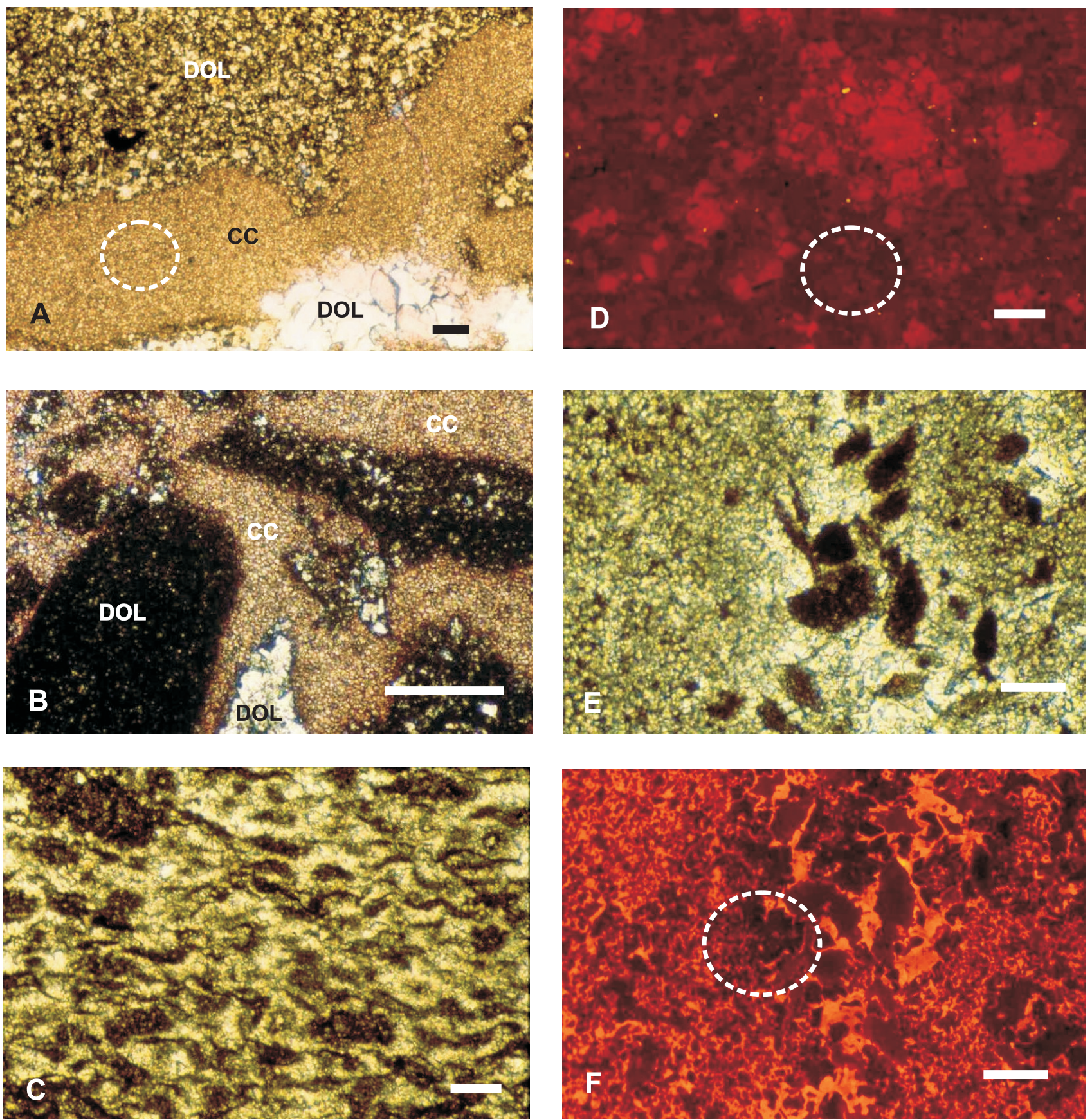

Figure 3. Photomicrographs of carbonate thin sections. (A): A stained section of the Bhander Limestone from Banakhuian under plane polarized light showing mudcrack filling calcites in a dolomite matrix. (B): A stained section of the Bhander Limestone from Rewa under plane polarized light showing ooids, oncoids and coarse dolospar cement in a microspar calcite matrix. (C): The Bhander Limestone from Ramnoi under plane polarized light. (D): A CL image of C showing medium red to non-luminescent components. (E): The Lakheri Limestone from Lakheri under plane polarized light. (F): A CL image of E showing bright red to dull red luminescent components. Length of scale is $200 \mu \mathrm{m}$. Dashed circles are sampling sites.

global seawater evolution curve suggests that the Bhander Limestone of the Son valley was deposited between 750 and $725 \mathrm{Ma}$. A similar exercise for the Lakheri Limestone of Rajasthan (figure 3D, 3E) yielded a much higher ratio of 0.70678 suggesting an early Late-Neoproterozoic age ( $\sim 650 \mathrm{Ma}$; Ray et al 2003). The age estimates of Ray et al (2003) are older than those of Kumar et al (2002) because their measurements are from well-preserved internal components, whereas the whole rock samples of the latter depict diagenetic signatures.

\section{Putting the pieces together}

A summary of all recent and reliable age data is given in table 1. All the age data, except 
for the Rb-Sr glauconite data from Chitrakut, are in the correct stratigraphic order. Therefore, the age of the Vindhyan Supergroup, at least for the Semri Group, is no longer an unsolved problem. In fact, the radioisotope ages and $\mathrm{Sr}$ isotope ratio data available today for the lower Vindhyans are amongst the best datasets for any Paleo-Mesoproterozic sequence in the world. The discrepancy of $\mathrm{Rb}-\mathrm{Sr}$ glauconite age data from Chitrakut sector (Kumar et al 2001) could possibly be a result of poor stratigraphic correlation. As for the Vindhyans of the Son valley, it is very clear now that the sedimentation started sometime prior to $1721 \mathrm{Ma}$ and continued until about $1600 \mathrm{Ma}$ without any major break. The basin wide unconformity above the Semri Group is also reflected in the age data, as there is a depositional hiatus lasting a few hundred million years. There is no question that the fossils found in the lower Vindhyan strata are Paleo-Mesoproterozoic in age. If so, then either the fossils of Azmi (1998) and Seilacher et al (1998) are the oldest known animal fossils in the world, or are questionable finds.

In spite of all the renewed efforts we still lack absolute chronology for the upper Vindhyan strata. The only attempt to directly date the Bhander Limestone formation by $\mathrm{Pb}-\mathrm{Pb}$ method, although it did not yield a good isochron, suggested an age of $\sim 650 \mathrm{Ma}$ (Ray et al 2003), which is not incompatible with the age estimated from Sr-isotope stratigraphy. Available information from relative dating suggests that the deposition of these strata started about $1100 \mathrm{Ma}$ ago and continued until after $650 \mathrm{Ma}$. The question whether the deposition continued into the Cambrian still remains open. The fact that many of the upper Vindhyan formations were deposited during a period when the Earth was experiencing severe glaciations would mean that they might contain information on the local environmental effects of such global events.

In the absence of reliable biostratigraphy and robust age data from all sectors, the problem of correlations would likely to continue. Paleomagnetic information may help, but is limited (e.g., Poornachandra Rao et al 2005). Chemostratigraphic correlations using $\mathrm{C}$ and $\mathrm{Sr}$ isotope stratigraphy are restricted to marine carbonate formations and always depend on the effective extraction of the most pristine values. Efforts by Kumar et al (2002) and Ray et al (2003) to this cause are noteworthy. However, not all the carbonate formations of the Vindhyan Supergroup yield pristine ratios that could be used for stratigraphy and correlation. Primary isotopic compositions of all the limestone formations of Rajasthan, except for Lakheri, have been obliterated by meteoric and deep burial diagenesis (Ray et al 2003). Dolostones in all the sectors are found to be of little use for isotope stratigraphy.

\section{Looking to the future}

Even after all the recent contributions we still have a long way to go in resolving issues pertaining to geochronology and stratigraphic correlations in the Vindhyans. In order to correlate different formations in various sectors we need absolute and relative age data from Vindhyans of Rajasthan and Chitrakut, in addition to more data from the Son valley. Paleomagnetic information would also be very handy in this correlation. Considering that several universities and institutes in India are now equipped with state-of-the-art Mass Spectrometers, it is only a matter of time before precise radioisotope ages on Vindhyan strata can be made available. Proper sample selections and use of appropriate dating methods would be the key to the success of geochronology. I envisage that $\mathrm{U}-\mathrm{Pb}$ dating of zircons from volcaniclastic sediments present in Kaimur and Rewa Groups (e.g., Chakraborty et al 1996), Re-Os dating of Bijaigarh Shale and whole-rock $\mathrm{Pb}-\mathrm{Pb}$ dating of Bhander/Lakheri Limestone will solve much of the mystery surrounding the upper Vindhyans. U-Pb dating of detrital zircons from sandstone formations can also throw some light on the age and help us to understand depositional hiatuses. One of the most exciting things happening in the geochronology of sedimentary sequences is the dating of diagenetic xenotime from siliciclastics by $\mathrm{U}-\mathrm{Pb}$ method (McNaughton et al 1999). In future if we can find and date xenotimes from the Vindhyan formations, we shall be able to resolve all the controversies surrounding the age of the supergroup and its fossil record.

\section{Acknowledgements}

I thank Chandan Chakraborty and Santanu Banerjee for their valuable comments.

\section{References}

Auden J B 1933 Vindhyan sedimentation in the Son valley, Mirzapur District; Geol. Surv. India Memoir 62 $141-250$.

Azmi R J 1998 Discovery of Lower Cambrian small shelly fossils and brachiopods from the Lower Vindhyan of Son Valley, Central India; J. Geol. Soc. India 52 381-389.

Bhattacharyya A 1996 Recent Advances in Vindhyan Geology; Geol. Soc. India Memoir 36 331p.

Bose P K, Sarkar S, Chakrabarty S and Banerjee S 2001 Overview of the Meso to Neoproterozoic evolution of the Vindhyan basin, central India; Sedim. Geol. 141 395-419. 
Bowring S A and Schmitz M D 2003 High precision zircon geochronology and the stratigraphic record; In: Zircon: Experiments, Isotopes, and Trace Element Investigations; (eds) Hanchar J M and Hoskins P W O, Rev. Mineral. Geochem. 53 305-326.

Brasier M 1999 Discovery of Lower Cambrian small shelly fossils and brachiopods from the Lower Vindhyan of Son Valley, Central India - discussion; J. Geol. Soc. India $\mathbf{5 3}$ 727-730.

Broecker W S and Peng T-H 1982 Tracers in the Sea (Palisades, New York: Eldigio Press) 691p.

Burke W H, Denison R E, Hetherington E A, Koepnick R B, Nelson H F, Ott J B 1982 Variations of seawater ${ }^{87} \mathrm{Sr} /{ }^{86} \mathrm{Sr}$ through Phanerozoic time; Geology 10 516-519.

Chakraborty P P, Banerjee S, Das N G, Sarkar S and Bose P K 1996 Volcaniclastics and their sedimentolgical bearing in Proterozoic Kaimur and Rewa Groups in central India; Geol. Soc. India Memoir 36 59-76.

Crawford A R and Compston W 1970 The age of the Vindhyan System of Peninsular India; J. Geol. Soc. London 125 351-371.

Frank T D, Lyons T W and Lohmann K C 1997 Isotopic evidence for paleoenvironmental evolution of the Mesoproterozoic Helena Formation (Belt Supergroup, Montana); Geochim. Cosmochim. Acta 61 5023-5041.

Faure G 1986 Principles of Isotope Geology (New York: John Wiley \& Sons) 588p.

Jahn B M $1988 \mathrm{~Pb}-\mathrm{Pb}$ dating of young marbles from Taiwan; Nature 332 429-732.

Jahn B M, Bertrand-Sarfate J and Macx N M J 1990 Direct dating of stromatolite carbonates from the Schmidtsdrif Formation (Transvaal Dolomite), South Africa; Geology 18 1211-1214.

Kathal P K, Patel D R and Alexander P O 2000 An Ediacaran fossil Sprigginia (?) from the Semri Group and its implication on the age of the Proterozoic Vindhyan Basin, Central India; Neues Jahr. Geol. Palaont.-Monat. 6 321-332.

Kumar A, Kumari P, Dayal A M, Murthy D S N and Gopalan K 1993 Rb-Sr ages of Proterozoic kimberlites of India: evidence for contemporaneous emplacements; Precamb. Res. 62 227-237.

Kumar A, Gopalan K and Rajagopalan G 2001 Age of the Lower Vindhyan sediments, Central India; Curr. Sci. 81 806-809.

Kumar B, Das sharma S, Sreenivas B, Dayal A M, Rao M N, Dubey N and Chawla B R 2002 Carbon oxygen and strontium isotope geochemistry of Proterozoic carbonate rocks of the Vindhyan Basin, central India; Precamb. Res. 113 43-63.

Kumar S and Srivastava P 1997 A note on the carbonaceous megafossils from the Neoproterozoic Bhander Group, Maihar area, Madhya Pradesh; J. Pal. Soc. India 42 141-146.

Kumar S 2001 Mesoprterozoic megafossils Chuaria-Tawuia association may represent part of a multicellular plant, Vindhyan Supergroup, Central India; Precamb. Res. 106 $187-211$

Mallet F R 1869 On the Vindhyan Series exhibited in northwestern and central Provinces of India; Geol. Surv. India Memoir 7(1) 1-129.

McArthur J M 1994 Recent trends in strontium isotope stratigraphy; Terra Nova 6 331-358.

McNaughton N J, Rasmussen B and Fletcher I R 1999 SHRIMP uranium-lead dating of diagenetic xenotime in siliciclastic sedimentary rocks; Science $\mathbf{2 8 5}$ $78-80$.

Mitra N D 1996 Some problems of Vindhyan Geology; Geol. Soc. India Memoir 36 1-4.
Mondal M E A, Goswami J N, Deomurari M P and Sharma K K 2002 Ion microprobe ${ }^{207} \mathrm{~Pb} /{ }^{206} \mathrm{~Pb}$ ages of zircons from the Bundelkhand massif, northern India: implications for crustal evolution of the BundelkhandAravalli protocontinent, Precamb. Res. 117 85-100.

Moorbath S, Taylor P N, Orpen J L, Treloar P and Wilson J F 1987 First direct radiometric dating of Archean stromatolitic limestone; Nature 326 865-867.

Morris S C, Jensen S and Butterfield N J 1998 Fossil Discoveries in India: Continued; Science $\mathbf{2 8 2} 1265$.

Narbonne G M and Gehling J G 2003 Life after snowball: The oldest complex Ediacaran fossils; Geology 31 27-30.

Oldham T 1856 Remarks on the classification of the rocks of central India resulting from the investigation of the Geological Survey; J. Asiatic Soc. Bengal 25 224-256.

Poornachandra Rao G V S, Mallikharjuna Rao J, Rajendra Prasad N P, Venkateswarlu M, Srinivas Rao B and Ravi Prakash S 2005 Tectonics Correlation of Upper Kaimur Group Sandstones by their Pelaomagnetic study; J. Indian Geophys. Union 9 83-95.

Rai V and Gautam R 1999 Evaluating Evidence of Ancient Animals; Science $\mathbf{2 8 4} 1235$.

Rai V, Shukla M and Gautam R 1997 Discovery of carbonaceous megafossils (Chuaria-Tawuia assemblage) from the Neoproterozoic Vindhyan succession (Rewa Group), Allahabad-Rewa area, India; Curr. Sci. 73 783-788.

Rasmussen B, Bose P K, Sarkar S, Banerjee S, Fletcher I R and McNaughton N J $20021.6 \mathrm{Ga} \mathrm{U}-\mathrm{Pb}$ zircon age for the Chorhat Sandstone, Lower Vindhyan, India: possible implications for early evolution of animals; Geology $\mathbf{3 0}$ 103-106.

Ravizza G and Turekian K K 1989 Application of the ${ }^{187}$ Re- ${ }^{187}$ Os system to black shale geochronometry; Geochim. Cosmochim. Acta 53 3257-3262.

Ray J S, Martin M W, Veizer J and Bowring S A 2002 U-Pb zircon dating and Sr isotope systematics of the Vindhyan Supergroup, India; Geology 30 131-134.

Ray J S, Veizer J and Davis W J 2003 C, O, Sr and Pb isotope systematics of carbonate sequences of the Vindhyan Supergroup, India: age, diagenesis, correlations and implications for global events; Precamb. Res. 121 103-140.

Sarangi S, Gopalan K and Kumar S $2004 \mathrm{~Pb}-\mathrm{Pb}$ age of earliest megascopic eukaryotic alga bearing Rohtas Formation, Vindhyan Supergroup, India: Implications for Precambrian atmospheric oxygen evolution; Precamb. Res. 132 107-121.

Sastry M V A and Moitra A K 1984 Vindhyan stratigraphy A review; Geol. Surv. India Memoir 116 109-148.

Seilacher A, Bose P K and Pflüger F 1998 Triploblastic animals more than 1 billion years ago: trace fossil evidence from India; Science 282 80-83.

Singh I B and Kumar S 1978 On the stratigraphy and sedimentation of the Vindhyan sediments in the Chitrakut area, Banda district (U.P.)-Satna district (M.P.); J. Geol. Soc. India 8 359-367.

Shields G and Veizer J 2002 Precambrian marine carbonate isotope database: version 1.1; Geochem. Geophys. Geosys. 3 U1-U12.

Srivastava A P and Rajgopalan G 1986 F-T Dating of Precambrian deposits of Vindhyan Group at Chitrakut, Banda District (U.P.-M.P.); In: Nuclear Tracks: Application to Earth Sciences, Space Physics and Nuclear Physics (ed.) K K Sharma, Dehra Dun, pp. 41-52.

Srivastava A P and Rajagopalan G 1988 F-T ages of Vindhyan glauconitic sandstone beds exposed around Rawatbhata area, Rajasthan; J. Geol. Soc. India 32 $527-529$. 
Srivastava A P and Rajgopalan G 1990 Glauconite ages of Vindhyan sediments in Rajasthan; Ind. J. Phys. 64 358-364

Srivastava A P, Rajagopalan G and Nagpaul K K 1985 Fission track ages of lower Vindhyan glauconitic beds at Mirzapur; Ind. J. Earth Sci. 12 89-92.

Srivastava D C and Sahay A 2003 Brittle tectonics and pore-fluid conditions in the evolution of the Great Boundary Fault around Chittaurgarh, Northwestern India; J. Struct. Geol. 25 1713-1733.

Valdiya K S, Bhatia S B and Gaur V K 1982 Geology of Vindhyanchal (New Delhi: Hindustan Publication Corporation) $227 \mathrm{pp}$.

Veizer J, Ala D, Azmy K, Bruckschen P, Buhl D, Bruhn F, Carder G A F, Diener A, Ebneth S, Godderis Y, Jasper T,
Korte C, Pawallek F, Podlaha O G and Strauss H 1999 ${ }^{87} \mathrm{Sr} /{ }^{86} \mathrm{Sr}, \delta^{13} \mathrm{C}$ and $\delta^{18} \mathrm{O}$ evolution of Phanerozoic seawater; Chem. Geol. 161 59-88.

Venkatachala B S, Sharma M and Shukla M 1996 Age and life of the Vindhyans - facts and conjectures; In: Recent Advances in Vindhyan Geology (ed.) A Bhattacharyya Geol. Soc. India Memoir 36 137-165.

Verma R K 1991 Geodynamics of the Indian Peninsula and the Indian Plate Margin; Oxford and IBH, 357pp.

Verma P K 1996 Evolution and age of the Great Boundary Fault of Rajasthan; Geol. Soc. India Memoir 36 197-212.

Vinogradov A P, Tugarinov A I, Zikhov C I, Stanikova N I, Bibikova E V and Khorre K 1964 Geochronology of Indian Precambrian; Report 22nd IGC New Delhi 10 $553-567$. 